\title{
The Impact of Text Genre on Iranian Intermediate EFL Students' Writing Errors: An Error Analysis Perspective
}

\author{
Kourosh Moqimipour ${ }^{1} \&$ Mohsen Shahrokhi \\ ${ }^{1}$ Department of English, Faculty of Humanities, Yasuj Branch, Islamic Azad University, Yasuj, Iran \\ ${ }^{2}$ Department of English, Shahreza Branch, Islamic Azad University, Shahreza, Isfahan, Iran \\ Correspondence: Mohsen Shahrokhi, Department of English, Shahreza Branch, Islamic Azad University, \\ Shahreza, Isfahan, Iran. Tel: 98-31-5350-2501. E-mail: shahrokhi1651@yahoo.com
}

\author{
Received: October 18, 2014 Accepted: November 20, 2014 Online Published: February 25, 2015 \\ doi:10.5539/ies.v8n3p122 URL: http://dx.doi.org/10.5539/ies.v8n3p122
}

\begin{abstract}
The present study aimed at analyzing writing errors caused by the interference of the Persian language, regarded as the first language (L1), in three writing genres, namely narration, description, and comparison/contrast by Iranian EFL students. 65 English paragraphs written by the participants, who were at the intermediate level based on their performance on a quick placement test, were analyzed by using Error Analysis (EA). The ideas of 15 teachers with more than six years of teaching in the field of TEFL were also sought through interview to validate the collected data. The results revealed that the first language interference errors fell into 12 categories: singular/plural form, modal auxiliary, subject-verb agreement, verb tense, infinitive gerund, pronoun, article, verb form, prepositions, sentence structure, word choice, comparison structure, respectively, and the number of frequent errors made in each type of written tasks was apparently different with regard to text genres. In narration, the five most frequent errors found were singular/plural form, modal auxiliary, subject-verb agreement, verb tense, and infinitive gerund, respectively, while the five most frequent errors in description were article, subject-verb agreement, modal/auxiliary, verb tense, and prepositions. The category for that of comparison/contrast comprised verb tense, singular/plural form, preposition, and subject-verb agreement respectively. The three errors of singular/plural form, verb tense, subject-verb agreement were the most frequent errors. The results reveals that different structural features required in a genre influences the writing errors made in the genre. Moreover, some pedagogical implications are provided based on the results.
\end{abstract}

Keywords: error analysis, interference, second language writing

\section{Introduction}

Writing is most often nominated as one of the most complex and complicated skills among the skills every second language learner is expected to master. One can refer to cognitive abilities required in this skill as one of the challenging requirements of writing. The writer has to overcome the steps in writing, namely prewriting, writing, and editing, in order to come up with final product. The skill of writing is required in a lot of situations including conveying a message in the form of letter, taking exams, and maintaining knowledge. As Trembley (1993) reports writing is a hard and risky skill.

Although writing in the first language is a demanding process, the task becomes more challenging when it comes to second language writing. A lot of research (e.g., Benson, 2002) has reported that the process of writing by fresh learners in a second language is interfered with the first language rules and structures. Writing in a foreign language often presents the greatest challenge to the students at all stages, particularly essay writing, because in this activity writing is usually extended and, therefore, it becomes more demanding than in the case of writing a short paragraph.

As Hyland (2003) believes error commitment is somehow inevitable in writings by EFL students because of the complexity of writing skills and because of the simultaneous processes of learning English and learning the writing skill that challenge the learners to a great extent. Research (Hyland, 2003; Ferris, 2002) indicates that EFL writing generally suffers from more errors, is less fluent and cohesive, and is shorter compared to other skills. Apart from writing errors made because of first language interference, overgeneralization and the level of difficulty are reported by Reid (1993) as other sources of error commitment in EFL students' writing. As Lalande 
(1982, p. 140) states "despite the fact that the students have studied certain rules of grammar, and some students exhibit remarkable consistency, they commit the same types of errors from one essay to the next".

Writing in general and essays in particular form problems to EFL students in our country. Teachers of writing classes are generally faced with students who have memorized a good amount of English vocabulary and grammar rules, but have seldom put that knowledge to practical use (Jalali, 2012). In many cases, the majority of these students are still translating words, phrases, and sentences from Persian to English with often very strange results. The challenge for teachers is to find methods to activate in a meaningful way the passive knowledge the students possess in terms of the writing skill, as well as to help the students become more proficient while working to eliminate some of their common errors. A better understanding of the L1 influence in the process of EFL writing will help teachers know students' difficulties in learning English. It will also aid in the adoption of appropriate teaching strategies to help beginning EFL students learn English writing skills better. As Richards and Renandya (2002, p. 303) claim; "there is no doubt that writing is the most difficult skill for L2 learners to master. The difficulty lies not only in generating and organizing ideas, but also in translating these notions into legible text". Yet, it is very necessary to look into the dynamics of writing and its teaching, as writing is a skill that not only is tested in every valid language examination, but also a skill that learners should possess and demonstrate in academic contexts.

EFL learners commit their errors as an inevitable part of their output; thus, errors can be used to measure the language performance of learners. Error Analysis (EA) is still an integral part of research in EFL studies. Errors committed by EFL learners are "systematic and reasoned" (Reid, 1993, p. 35). Drawing upon these errors, EFL instructors can monitor the learners' development and performance and "take the remedial action afterwards" (Shahrokhi \& Lotfi, 2012, p. 641).

The main objective of the current study is to identify the English writing errors made in different text genres, namely comparison/contrast, descriptive, and narrative by EFL students in Yasuj, Iran. Based on the above objective the study is going to check whether each genre has particular types of errors. According to the problems mentioned and purposes of the study the following questions were formulated to be saught in the current study:

1) Are Iranian EFL students' writing errors related to the interference of both English and Persian?

2) Is it feasible for Iranian L2 student writers to enhance their writing accuracy, in respect to error categories of narrative, descriptive and comparison/contrast writing genres?

\section{Review of Literature}

The number of studies conducted to investigate writing errors has been increased recently as writing is considered an important academic skill in academic circumstances and outside as well. It is clear that "writing structures our relations with others and organizes our perception of the world" (Bazerman \& Paradis, 1991, p. 3; as cited in Khuwaileh \& Al-Shoumali, 2000). Therefore, a brief background of the theories that form a platform for the study of writing errors from an EA perspective seems contributive.

\subsection{The Use of Error Analysis}

Analyzing errors to determine one's L2 (and L1) competence is controversial. In L1 writing, the need for 'fluency' is often the focus instead of having writers worry about committing errors and mistakes. Latif (2009) stated that fluency is important in L2 writing as investigating fluency can inform us of the difficulties students may encounter in producing their written texts in particular and in assessing writing in general.

According to James (2001), "in the 1950s and 1960s the favored paradigm for studying foreign/second language learning and organizing its teaching was Contrastive Analysis" (p. 4). According to Contrastive Analysis Hypothesis $(\mathrm{CAH})$, the first language interference is the major source of barrier to the acquisition of a new language. Since $\mathrm{CAH}$ failed to practically account for the errors committed by second language learners, EA emerged as a complementary approach to account for the errors committed by second language learners. Compared to CAH, EA considered every feasible source of errors in addition to first language interference.

Based on EA, errors indicate students' second language learning progress. Interlanguage, as described by Selinker (1972), is a linguistic system developed by second language learners within the course of language acquisition and it includes a variety of both first and second languages elements. Errors made by second language learners are most often identified in interlanguage. The nature of interlanguage provides an opportunity for second language learners to be able to formulate and test hypotheses of the grammar of second language; this is the process through which the learner can internalize the second language rules. The process of hypothesis formulating and testing does not flourish free of error commitment. As Ellis (1985) believes, scrutinizing errors 
made by language learners is not what the teacher is interested in, however it is a contributive technique that sheds light on the progress of learning.

\subsection{Contrastive Rhetoric}

Although many criticisms addressed CAH, it could manage to be one of theories in the field of SLA and more specifically in studies of writing. Contrastive rhetoric, as a section of $\mathrm{CAH}$, refers to the effect of one's first culture and language on one's second language writing. The applicability of contrastive analysis to writing errors has been highlighted by Ellis (2005). The writer believes that contrastive analysis survived in the form of contrastive rhetoric (Ellis, 2005). As Connor (1996) reports contrastive rhetoric is a research line in SLA that deals with errors identified in the writings of second language learners. It further makes an attempt to account for the errors with regard to rhetorical strategies available in the first language system. The impact of transfer from the first L1 to L2, reported in contrastive rhetoric and contrastive analysis studies, are among the major contributions of applied linguistics.

\subsection{Definition of Errors}

The terms mistake and errors are used interchangeably in non-technical situations. However, in EA paradigm the terms have functional separation. Mistakes are made due to such reasons as ignorance, fatigue, lack of attention as stated by Richards and Schmidt (2002). Therefore, once attention is called mistakes can be corrected without any external assistance by the person. On the other hand, errors are rule based; that is, inadequate mastery of some target language rules leads to the production of linguistic items both written and oral those are not acceptable and familiar to native or fluent speakers.

Two other important definitions are worth stating here. Norrish (1987, p. 7) defines errors as "a systematic deviation, when learner has not learnt something and consistently gets its wrong". A second definition is put by Cunningworth (1987, p. 87) as "errors are systematic deviations from the norms of the language being learned". One can infer that the main feature of an error, that is 'systematic deviation', is a deviation that occurs over and over. Following Cunningworth (1987), the current study considers errors as a systematic deviation from targeted rule or rules.

\subsection{The Classification of Errors}

Brown (2000, p. 220) in his analysis of Corder's model (1971), states that "any sentence uttered by the learner and subsequently transcribed can be analyzed for idiosyncrasies". He makes a distinction between overt and covert errors. "Overtly erroneous utterances are unquestionably ungrammatical at the sentence level. Covertly erroneous utterances are grammatically well-formed at the sentence level but are not interpretable within the context of communication (Brown, 2000, p. 220)".

Thus, to analyze students' errors, it is necessary to determine the sources of errors. Regarding the aforementioned sources of errors, it could be understood that the two main sources are intralingual and interlingual errors. What follow is a brief review of these errors.

\subsubsection{Intralingual (Developmental) Errors}

Research shows that students' incomplete or wrong learning of the second language elements leads to error commitments termed intralingual errors (Fang \& Xue-mei, 2007). As reported by Erdogan (2005) the outcome of forming concepts and formulating hypothesis by learners who have obtained marginal knowledge of the second language is the occurrence of intralingual errors. For instance, EFL writers fail to complete a written task as required because of inadequate competence of the target language lexical and syntactic elements, and the inadequacy occasionally leads to some degrees of confusion regarding the new language that is supposed to be mastered. The speech of second language learners also suffers from common intralingual errors, though the errors can be analyzed by instructors in order to identify the strategies employed by the learner.

\subsubsection{Interlingual (Interference) Errors}

Errors that stem from first language interference are called interlingual or transfer errors. In case transfer impedes the progress of learning the new language, it is called negative transfer; however, if the transfer facilitates the progress is considered as positive transfer. Selinker (1972) first used the term interlingual. To Selinker (1972) the term interlingual meant the systematic knowledge acquired by the learner regarding the target language; the systematic knowledge, however, was not similar to neither to learners' mother language nor to the target language. Transfer is defined as "a generalization of learned responses from one type of situation to another (Webster's third new world international dictionary, 1986)". Therefore, Language transfer as a significant cognitive variable can play a key role in writing errors. 


\subsection{Previous Research on the Relation Between L1 Interference and L2 Writing Errors}

Identifying errors committed by students due to L1 interference is the first step language instructors should take to help student writers improve their writing performance. Therefore, a lot of research has been conducted in the last few years to investigate the impact of L1 interference on L2 writing.

For instance, Lakkis and Abdel-Malak (2000), in their study of Arab EFL learners, investigated the impact of Arabic prepositional knowledge transfer on English. Both positive and negative transfer were examined in order to help teachers identify problematic areas for Arab students and help them understand where transfer should be encouraged or avoided. In particular, they concluded that "an instructor of English, whose native language is Arabic, can use the students' L1 for structures that use equivalent prepositions in both languages". However, "whenever there are verbs or expressions in the L1 and L2 that have different structures, that take prepositions, or that have no equivalent in one of the languages, instructors should point out these differences to their students" (Lakkis \& Abdel-Malak, 2000, p. 30).

In the context of Iran, Sadeghi (2009) performed a study on collocational differences between L1 and L2 and documented that $72.1 \%$ of high school students failed to use collocations correctly. He further traced $83.75 \%$ of errors to interlingual interference (Persian as L1) and $16.25 \%$ of errors to intra-lingua interference (English or other factors). Behjat and Sadeghi (2010) investigated if the Threshold Hypothesis can account for Iranian EFL learners' grammar development at different levels and found out that transfer of L1 grammar operates differently at different stages.

ESL/EFL learners also find diverse genres of writing (e.g., argumentative and creative) difficult. Izadi-Agha (2007) investigated English writing errors made by 25 Iranian students enrolled in ESL programs at various universities throughout California. Errors were found in both argumentative and creative modes. Izadi-Agha identified 820 errors and divided the errors into 10 major categories: $14.5 \%$ of mistakes concerned the usage of articles, $10.2 \%$ prepositions, $9.3 \%$ tense, $9.2 \%$ grammatical number, $8.6 \%$ conjunctions and connectors, $5.3 \%$ adjectives, $5.5 \%$ subject and predicate, $4.8 \%$ verb phrases, and $4.8 \%$ pronouns. Additional errors found in Izadi-Agha (2007) included the omission and misuse of prepositions, errors in terms of number, and in adjective use. These participants did not know how to form the correct forms of adjectives, and they used nouns as adjectives.

Sattari (2012) described and analyzed Persian English learners' grammatical errors in writing that mostly originate from the mother tongue. This study showed that a great number of persistent errors made by these learners at elementary levels can be traced to the influence of the mother tongue. Concerning interlingual errors, errors made by the participants were mostly about use of third person singular -s/es, plural s/es, articles, errors in the use of correct prepositions, errors caused by borrowing and loan translation. Regarding intralingual errors, the most serious problem was overgeneralization.

Abbasi and Karimian (2011) investigated grammatical errors among Iranian Translation Students according to Keshavarz's (2005) model. Their findings surprisingly showed that 98 percent of the students had grammatical problems. Furthermore, most of errors were of interlingual errors, indicating the influence of the mother language. In a study conducted by Nayernia (2011), written sentences of learners were analyzed to find out what proportion of the learners' errors were intralingual errors and whether the native language plays a significant role in learners' difficulties in learning the target language. Her findings revealed that only 16.7 percent of the errors were interlingual errors and most of errors could be attributed to target language system. This is in contrast with Abbasi and Karimian's (2011) finding.

\section{Methodology}

\subsection{Participants}

The main participants of this study were a total of 70 Iranian undergraduate university students majoring in teaching English as a foreign language at Azad and State universities of Yasuj in Kohgiloyeh and Boyerahmad province, Iran. Their age range was between 20 and 25 years. The participants' native language was Persian. Also, the participants were both males and females, 30 males and 40 females. They were selected from among 153 Iranian undergraduate university students majoring in teaching English as a foreign language based on their performance on a proficiency test.

In addition to the EFL students, the ideas of 15 teachers with more than six years of teaching in the field of TEFL were also sought through interview to validate the collected data. The teacher participants were all BA holder including 10 male and 5 female, ageing 29 to 37. 


\subsection{Materials and Instruments}

For the purpose of obtaining data and identify the most common errors which may occur in students' writing, the researchers conducted this study by using the following instruments for data collection:

1) A Quick Placement Test (QPT). As reported by Shahrokhi and Moradmand (2014), the QPT is a multiple-choice test with 50 items, testing situations (five items), cloze passages (25 items), and grammar and vocabulary (20 items). The QPT was administered to 153 students as the population of the study and based on the results obtained 70 particpants whose overal language proficiency was at intermediate level with regard to the QPT scale were selected as the homogenous target participants of the study.

2) Writing Samples: The corpus on which this study was mainly based included 70 essays of which 5 essays were excluded due to incomprehensibility and illegibility. 65 essays targeted, were of approximately 120 to 200 words each, written in classes in two universities of Yasuj. The purpose of collecting the samples was to analyze the most common errors made by Iranian EFL students in their writing with regard to different genres.

3) Semi-structured interviews: 15 Teachers of English were interviewed to obtain qualitative data regarding students writing skills.

\subsection{Data Collection Procedure}

At the initial stage of data collection, permission was sought from the teachers of the targeted classes in the two universities involved to allow 50 minutes of the whole class time to write an essay on topics regarding three different writing genres namely narrative, descriptive, and comparison/contrast. Both teachers and students were told about the aim of this writing activity which was to analyze the students' errors in EFL writing. The teachers were cooperative and willing to participate in accomplishing this study. The students were provided with the topics "The Biography of a Famous Person" (a narrative essay), "Description of Norouz Holiday in Iran" (a descriptive essay), and "The National TV Programs and the Satellite Programs" (comparison/contrast). The participants were requested to write on one of the three mentioned topics in 150 to 250 words. They were also given sufficient time to write. In order to get more reliable and uniform data, the participants were asked to write their compositions in about three paragraphs, and to write on their own without consulting their friends, teachers, or the researchers. Moreover, they were not told about the area of their writing which would be studied; had they been told, they might have underused or overused such words. As a result 70 essays were collected, but due to the incomprehensibility and illegibility, 5 essays were excluded. The final number of acceptable essays was then 65 .

In the next phase of the study, five EFL teachers were asked to participate in semi-structured interviews to obtain qualitative data regarding their ideas about students writing skills. All the interviewed teachers had been teaching English for more than 6 years, that is to say, they had enough expertise in dealing with writing skill.

\subsection{Data Analysis}

The collected data were scrutinized by the researchers to identify the type and frequency of errors made in every text type. For the purpose of obtaining maximum reliability of the data analysis results, inter-rater reliability technique was followed. To this end, other than the researchers, two M.A. graduates of TEFL who were experience teachers as well were asked to identify errors in the corpus. The results of data analysis indicated some 97.2 percent agreements on the type and frequency of analyses made by the researchers and the raters. The other 2.8 percent discrepancies among the researchers and raters regarding the type and frequency of errors were excluded for the improvement of reliability of data analysis. The results were further subjected to descriptive statistical procedures and tables and figures of frequency and percentages were provided. The software SPSS (version 20) was employed for statistical analysis of the data. The data collected through semi-structured interview was analysed qualitatively and supplemented the quantitative analysis of the data as reported in the following sections.

\section{Results}

As mentioned earlier, the current study was after finding EFL students' errors in EFL writings in different texts genres with the aim of tracing any sign of L1 interference. The model for analyzing the data in this study was based on that of Sridhar (1985).

\subsection{Interlingual Interference}

The interligual errors in this study are classified as follows: verb tense, singular/plural markers, modal/auxiliary, prepositions, articles and pronouns, infinitive/gerund, subject-verb agreement, verb form, comparison structure, sentence structure, and word choice (analyzed at both word and sentence levels). Total number of interlingual 
errors amounted to 1161 out of 1435 total number of errors which was more than 80 percent of errors (see Figure1).

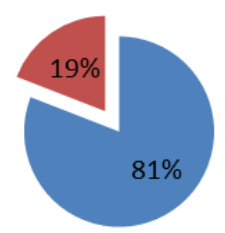

Figure 1. The frequency difference between Interlingual and Intralingual errors

As can be clearly seen in Figure 1, the interlingual error counts were much more than that of intralingual errors. This means that transfer from L1 to L2 happened more than errors caused by interlanguage or learning errors. What is more, L1 interference, for sure, has been the byproduct of this transfer which is better to be called as negative transfer.

The classification of interligual errors (L1 Interference) for narrative writings was as shown in Table 1. The total number of interligual errors was 342 cases and their distributions according to their categories were as presented in the table. It is clear that the singular/plural form was the dominant error category $(16.37 \%)$. Then, the second most frequent error was the modal/auxiliary type (13.74\%). The subject-verb agreement error $(12.57 \%)$ registered the as the most frequent type. Apart from these types of errors, the other error categories were: verb tense $(11.40 \%)$, infinitive/gerund $(10.23 \%)$, pronouns $(9.35 \%)$, article $(8.18 \%)$, verb form $(4.67 \%)$, preposition $(4.67 \%)$, sentence structure $(3.80 \%)$, word choice $(2.92 \%)$, and comparison structure $(2.04 \%)$, respectively.

Table1. Errors found in narrative writing

\begin{tabular}{lll}
\hline Error Types & Frequency & Percentage \\
\hline 1. Singular/Plural form (Sing/Plu) & 56 & 16.37 \\
2. Modal/Auxiliary (Mod/Aux) & 47 & 13.74 \\
3. Subject-verb agreement (SV) & 43 & 12.57 \\
4. Verb tense (VT) & 39 & 11.40 \\
5. Infinitive/Gerund (Inf/Ger) & 35 & 10.23 \\
6. Pronoun (Pron) & 32 & 9.35 \\
7. Article (Art) & 28 & 8.18 \\
8. Verb form (VF) & 16 & 4.67 \\
9. Preposition (Prep) & 16 & 4.67 \\
10. Sentence structure (SS) & 13 & 3.80 \\
11. Word choice (WC) & 10 & 2.92 \\
12. Comparison structure (Comp St) & 7 & 2.04 \\
\multicolumn{1}{c}{ Total } & 342 & 100 \\
\hline
\end{tabular}

It could be concluded that singular/plural form was the most prominent feature in the writings of Iranian EFL students regarding narrative genre. The students made this kind of errors since singular/plural form is absent in their L1 (Persian). The number of third person singular subject in Persian is revealed by the subject itself and the verb merges with no specific inflection to indicate the subject is third person singular. It seems that inflecting the verb in English to signal the third person singular subject is redundancy to Persian learners of English. The redundancy sometimes misleads the learner to underestimate the significance of English inflection '- s', though it 
is frequently used in English. Consequently, learners may ignore the use of it (see examples 1-5).

$1-*$ they very weaks and poors.

2-* When new year beginø.

$3-*$ Every one spendø their money when go out.

4-* all peoples heard the voices.

5-* The man discovered every things.

Plural/singular noun distinction is available in English and Persian as well. The general rule regarding the meaning of suffixes used in Persian and English to make plural nouns is similar, though there are differences in the use of plural nouns. The suffices '-s' and '-es' are used at the end of nouns to make them plural in English, no matter whether the noun is animate or non-animate; in Persian, animate nouns are made plural when suffixed with (ن) and (ه) is suffixed to make plural animate nouns. The major difference between Persian and English exists in the use of modifiers with plural/singular nouns. In contrary to English, there is no agreement between the noun and quantifier as far as the number is concerned. In other words, in Persian the use of singular nouns with quantifiers is grammatical. This may lead to the production of erroneous forms by Persian EFL as indicated in the following examples.

$$
\begin{aligned}
& \text { 6-* I came to Yasuj } 6 \text { monthø ago. } \\
& \text { 7-* He had a lot of problemø. } \\
& \text { 8-* She had two brother } \varnothing \text { and three sister } \varnothing
\end{aligned}
$$

Modal/Auxiliary errors were the second most problematic area in this genre. Because Persian does not have all equivalent words for 'did', 'have', 'do', 'be', and 'does' as auxiliaries, EFL learners have problem with writing interrogative and negative sentences in which the above mentioned auxiliaries have to be used. The problem was not very frequent with modals because some of them, e. g. 'be', are also used in Persian; however, Persian EFL students seemed to have problems with past modals (examples 9-12). Moreover, the participants depended in their writing mostly on using simple present modals for all cases.

$$
\begin{aligned}
& \text { 9-* He don't go to university. (did not) } \\
& \text { 10-* People try don't to sit with him. (not to) } \\
& 11 \text {-* It can been said that he is a bad football player. (be) } \\
& \text { 12-* First of all a teacher have a good job. (has) }
\end{aligned}
$$

In an attempt to show that events happen and happened, the respondents in this study over-generalized the use of auxiliary verbs and committed the errors above. The learners also displayed confusion in the use of English auxiliaries. Indeed, where the auxiliaries are concerned, Iranian learners have no frame of reference, and therefore there is a possibility that the absence of such auxiliaries in Persian is indirectly responsible for learners' errors.

As examples 13 and 14 show, the third category of problem was that of subject-verb agreement. Even though this agreement is also true for Persian language, students seem to have difficulty in applying this type of grammatical rule. In addition to the misuse of verbs, the participants also tended to omit the "to be" verbs in continuous tenses.

13-* I were playing/ He ø talking. (was)

14-* The earthquakes is very terrible. (are)

As the forth category in this genre (narrative), verb tense is the most common type of error committed by Persian EFL learners. Because of the fact that simple present tense in Persian covers meaning of simple and progressive in English (see examples 15 through 19), these errors are of negative transfer because there is no mirror equivalent forms between L2 continuous, perfect and future and these in L1.

15-* She speaking now.

16-* They talking highly.

17-* I go to a kindergarten when I was five.

18 -* We knew that we can't find them.

19-* They were tired and they sleep all day. 
Infinitive/gerund ranked fifth in the list of error category. This error is caused by failing to observe the restrictions of L2 existing structure. Based on James (1998), the example of this error type is addressed in the sentence "I would enjoy to learn". This is considered an error stemming from the overlooking co-occurrence restrictions; the word 'enjoy' co-occurs a gerundial complement.

The example below, in addition, demonstrates the ignorance of the rule of 'infinitive', in which the word 'to' needs to be placed before the bare form of the verb. This sort of error is frequently found among EFL writers when those linguistic elements do not occur together. The students' explanation for this error is that they are too focused on the familiar word 'meeting' and fails to see the relationship between the words 'willing to' and 'meeting'. The other kind of problem happened in participants' writing with the verb 'enjoy' in which the students used infinitive form of the verb instead of gerund after this verb.

20-* I am willing to meeting with famous people. (*meet)

21-* He enjoyed to play volleyball.

The next category of difficulty was that of pronouns. In Persian and English pronouns do not have a one-to-one equivalent. Persian, for example, does not have any equivalent form for 'it' as a gender-neutral pronoun. Therefore, in order to refer to non-animate things or concepts, Iranian EFL learners resort to demonstratives, e. g. 'that', or subject pronouns like 'he' or 'she'. There are also some errors committed due to the confusion of possessive pronouns adjectives with object pronouns, e.g., 'his/him'. This type of problem could be attributed to L1 interference since the students substituted the pronouns which they use in Persian for English. The followings illustrate this aspect clearly:

22-* she had two girls from his

23-* the man when he saw the accident, he called the policemen.

$24-*$ so that was very difficult for him to....

$25-*$ he bought a car that he can go to work by that

The use of definite article 'the' incorrectly was one of the most frequent errors observed among Iranian EFL learners. As this article is absent in Persian, the learner has difficulty in learning and using it and produces erroneous sentences. The students may omit or add articles to a noun which again demonstrates L1 transfer. See the following examples:

26-* But in ø United States.

27-* At the end of $\varnothing$ term.

28-* $\varnothing$ birthday was on Sunday.

29-* I went to ø gym.

30-* I went to Ø Park.

$31-*$ I went to ø north of Iran.

32-* In Tehran ø weather is very raining.

33-* The women are equal to the men.

34-* The money is very important.

$35-*$ The education is free for all peoples.

36-* The success is a final aim of every human being.

As far as the articles ' $a$ ' and 'an' are concerned, the category of articles in Persian is again unmatched with that of English resulting in such errors as follows.

37-* he was $ø$ very clever and good student.

38-* our country has a old history.

The students also did many grammatical errors regarding verb form. Some participants made awkward errors on verb forms of simple present and simple past, and some were very confused about the use of modal auxiliaries. This kind of error indicated the students' poor knowledge of basic English verb forms.

39-* If he studied harder, he will found a good job.

40-* She was took mathematics in high school. 
41-* He was not live with his parents.

42-* People exercise because they think that they will be relaxed. (relax)

Errors in the use of prepositions were ranked ninth after verb form. Most of these errors were caused by interference from Persian. Choosing a wrong preposition, omitting a required preposition, and inserting an unnecessary preposition after an adjective were in this category of errors. By looking at the following examples, it can be found that most of the cases of substitution occurred due to first language interference, and the primary source of addition errors seemed to be intralingual factors. However, it seems that neither the students' L1 influence, nor the influence of the target language can account for their omission errors, but rather, carelessness and lack of attention.

a. Omission

43-* I am afraid earthquakes.

44-* They wanted to connect_internet...

45-* I liked both_the games.

46-* We came back home_Friday.

b. Addition

47-* I helped to my mother do the housework.

48-* The rapid increase of prices effects on people's lives.

49-* We called to the police after the accident.

\section{c. Substitution}

50-* We watched the candidates' debate in TV.

51-* The rude boy threw stones to us.

52-* I was thinking to the soccer game when the teacher came in.

Regrding sentence structure, the most difficult point resulting in L1 transfer was a failure to arrange words in a sentence in the right order based on word-order regulation in English, such as in the following.

53-* He was a fat boy and friendly. (friendly, fat boy)

54-* Have many trees in the university. (There are)

55-* How we can stop watch satellite?

56-* Many problems we have to face with satellites.

57-* I very worry.

58-* Our teacher explains the lessons always kindly.

On the level of word choice errors, the lexical errors counted were either a word or two words (e.g. collocation) or whole phrases or sentences. Examples of lexical errors due to L1 transfer can be seen in the following examples:

59-* He started to learn me how.... (teach)

60-* The children went to special schools. (private schools)

61-* My brother travelled outside the country. (aboard)

$62-*$ they theift the house. (stole)

$63-*$ they remembered me to go at once. (reminded)

64-* In the Spring, the flower begin to open. (bloom)

65-* I cut a promise to help others people.

66-* I say with my self....

It is obvious that most of the errors are funny ones and the sign of L1 transfer. Here, they occur when learners translate directly from L1 to convey their ideas in English. Another reason for making such errors is due to the learners' limited English vocabulary (see examples 60, 61, 64 and 65).

Comparison structure $(2.04 \%)$ was the problem which ranked the last one in the category for narrative writing. 
Actually, this problem could be attributed to the low frequency of comparison and contrast use in this genre; in narrative writing the students wrote about the biography of a famous person and they did not need to compare and contrast very much. Here, again, students made some erroneous structures which could be related to their lack of English language knowledge not to L1 interference.

$67-*$ He was more smart than his classmate.

68-* She study hardest than me.

69-* They very bigger than Ali. (older)

70-* He has taller hair than Mehdi. (longer)

Table 2. Errors found in descriptive writing

\begin{tabular}{lll}
\hline Error Types & Frequency & Percentage \\
\hline 1. Article (Art) & 70 & 17.41 \\
2. Subject-verb agreement (SV) & 61 & 15.17 \\
3. Modal/Auxiliary (Mod/Aux) & 52 & 12.93 \\
4. Verb tense (VT) & 42 & 10.44 \\
5. Preposition (Prep) & 35 & 8.70 \\
6. Sentence structure (SS) & 33 & 8.20 \\
7. Singular/Plural form (Sing/Plu) & 28 & 6.96 \\
8. Verb form (VF) & 20 & 4.97 \\
9. Pronoun (Pron) & 20 & 4.97 \\
10. Infinitive/Gerund (Inf/Ger) & 19 & 4.72 \\
11. Word choice (WC) & 13 & 3.23 \\
12. Comparison structure (Comp St) & 9 & 2.23 \\
\multicolumn{1}{c}{ Total } & 402 & 100 \\
\hline
\end{tabular}

As shown in Table 2, unlike narrative writing, Singular/Plural was not recorded as the most frequent error in descriptive writing since the students rarely made errors in terms of Singular/Plural forms. However, the three most frequent errors were article (17.41\%), subject-verb agreement (15.17\%), and modal/auxiliary (12.93\%), relatively similar to the errors in narrative writing, except for the category of prepositions which has replaced with that of infinitive/gerund. Interestingly, verb tense form (10.44\%) became students' fourth most frequent problem when writing descriptive paragraphs.

Because of the writing topic assigned "Description of Norouz Holiday in Iran", the student writers had to describe Norouz by using a lot of nouns and simple present verbs to write about the customs and events in this holyday. Consequently, the misuses of prepositions, sentence structure, and singular/plural form were consistently seen in their paragraphs. Besides the aforementioned L1 interference categories, the other error types found in descriptive writing were as verb form (4.97\%), pronoun (4.97\%), infinitive/gerund (4.72\%), and word choice $(3.23 \%)$. comparison structure $(2.23 \%)$. 
Table 3. Errors caused by L1 interference found in comparison/contrast writing

\begin{tabular}{lll}
\hline Error Types & Frequency & Percentage \\
\hline 1. Verb tense (VT) & 75 & 17.98 \\
2. Singular/Plural form (Sing/Plu) & 62 & 14.86 \\
3. Preposition (Prep) & 50 & 11.99 \\
4. Subject-verb agreement (SV) & 47 & 11.27 \\
5. Comparison structure (Comp St) & 36 & 8.63 \\
6. Modal/Auxiliary (Mod/Aux) & 34 & 8.15 \\
7. Article (Art) & 26 & 6.23 \\
8. Word choice (WC) & 24 & 5.75 \\
9. Pronoun (Pron) & 20 & 4.79 \\
10. Infinitive/Gerund (Inf/Ger) & 18 & 4.31 \\
11. Verb form (VF) & 17 & 4.07 \\
12. Sentence structure (SS) & 8 & 1.91 \\
\multicolumn{1}{c}{ Total } & 417 & 100 \\
\hline
\end{tabular}

As can clearly be seen from the data in Table 3, a genre significantly affects error types. In narrative and descriptive writing, comparison was the least frequent error the students made in their written work. On the other hand, when they were assigned to write a comparison/contrast paragraph, some errors regarding comparison structure were constantly made as they needed to use comparative patterns to express their thoughts. Not surprisingly, verb tense (17.98\%), singular/plural form (14.86\%), preposition (11.99\%), and subject-verb agreement (11.27\%) were the four most frequent errors-somewhat similar to narrative and descriptive writing. Comparison structure $(8.63 \%)$ ranked fifth in the list for the mentioned genre. The other common error types found in comparison/contrast writing were modal/auxiliary $(8.15 \%)$, article $(6.23 \%)$, word choice $(5.75 \%)$, pronoun $(4.79 \%)$, infinitive/gerund (4.31\%), verb form (4.07\%), and sentence structure (1.91\%)

In sum, it is reasonable to say that although there is considerable overlap in the common errors caused by L1 interference, the number of errors of specific categories varied, depending on a particular genre. In order to provide good feedback for students' writing, error categories of each text type should be taken into consideration.

\subsection{Intralingual Interference}

This section provides a theoretical review on learning strategy-based error which can result from intralingual errors in EFL writing. The total number of intralingual errors amounted to 274 out of 1435 total number of errors which was less than 20 percent of errors (see Figure 1).

This error can be defined as the deviate form of language caused by conflicting information of the target language. Unlike those interlingual errors, which are traced to first language transfer, Scovel (2001, p. 51) identifies intralingual errors as:

“...the confusion a language learner experiences when confronting patterns within the structure of a newly acquired language, irrespective of how the target language patterns might contrast with the learner's mother tongue".

This can be noted that intralingual errors are not related to the first language transfer, but contributed by the target language itself. Building on the foundation of the source of error mentioned above, the following learning strategy-based errors can be mentioned: false analogy, misanalysis, incomplete rule application, exploiting redundancy, overlooking co-occurrence restrictions, hypercorrection (monitor over use) and overgeneralization, or system-simplification. However, from among these errors, false analogy and overgeneralization (accounted to 274 out of 1435 total number of errors, about $19 \%$ of total errors) were two problems which were noticed in the present study. 


\subsubsection{False Analogy}

English writing conventions are one of the other frequent errors committed by Iranian EFL writers. For instance, capitalizing the proper nouns or the first word of every sentence is among the writing conventions of English. However, Iranian EFL writers most often ignore the rules because the conventions are absent in their first language. As exemplified in examples 71 to 74, proper nouns, name of cities and sometimes name of monthes are not capitalized by some learners.

71-* The seventh of tir

72-* .....to yasuj....

73-* ali daei....

74-* they sent the present to pouya....

Furthermore, the nature of Persian language provides Persian native speakers with the opportunity to write long sentences separated by commas. For instance, four sentences can be linked together by commas. This Persian language attribute is observed to be transferred to English writings of Iranian EFL learners resulting in long unacceptable English sentences. Last, the wordiness or redundancy style of Persian writing appeared in the students' written English. They were unaware of the superfluity of important words in their paragraphs.

\subsubsection{Overgeneralization}

Overgeneralization is the process of extending the application of a rule to items that are excluded from it in the language norm. The process usually results in the formation of erroneous sentences. The use of article 'the' is observed to be over generalized by Iranian EFL learners as illustrated below.

75-* In the Canada....

76-* we played the football outside.

77-* He usually visits the his brother home at weekend.

78-* I went to the Isfahan.

79-* They earn experience.

80-* Anything are more cheap in my country.

81-* Per Iran it's cheap as compared with US.

82-* Per Elizabeth's birthday.

83-* I usually go running to the home.

The learner is familiar with the formation of wh-question in English, but does not know that the rule does not apply to an embedded sentence.

84-* If you want to know what did I do....

85-* He asked me do you know who was Hafez?

\subsection{Results of the Teachers' Interviews}

In order to get a clearer picture about what causes Iranian EFL students to commit many grammatical errors in their English writing essays, recognizing perspectives of English teachers is necessary and beneficial. The 15 interviewed teachers recognized the positive effects teachers can exert on their students' developing writing skills. Some interviewed teachers put much responsibility on teachers for the decline of their students' writing skill. What follows are some of the teachers' explanations regarding the weakness of the Iranian students in English writing skill. The interviewee teachers were asked:

1) Why do you think Iranian university students suffer from weakness in English writing skill?

2) Which one do you think is responsible for writing weakness, teaching methodology, teachers, or students?

3) How can you help with developing students' English writing skill in our country?

Regarding the first question, one of the teachers said, "It is really a big problem among most students at different stages. I think this is due to many reasons including lack of vocabulary, lack of motivation, the effect of mother tongue and unavailability of use of the language outside of class."

As for the second question, regarding factors other than teaching methodology, one teacher talked about entitlement. He explained that there is a broad sense of entitlement among students - that students believe they 
deserve a passing grade, or even a superior grade, simply because they registered, paid tuition, attended class, and/or turned in homework, with the actual quality of their work being a less relevant factor. "Students have a sense of entitlement-which they are here to receive a degree, not to work for it" they said. Additionally, two of the respondents perceived students as having expectations that they (faculty) should be readily available to meet student needs and to share responsibility for students' performance.

Three of the teacher respondents made a further connection with what they saw as students' unwillingness to struggle in order to reach mastery. For some, this unwillingness translated into students wanting to be "spoon-fed" the correct responses for tests and other assessments.

Another teacher said, "It is an accumulated weakness resulting from previous years. Lack of vocabulary and writing activities is the major reasons, but the students' lack of interest is a big problem."

Some teachers blamed the teacher for the weakness of their students' English skill. They believed that the teacher plays a great role in developing the students writing skill. They also thought that the teacher's method in teaching writing can be sometimes blamed for the students' weakness in writing. Some teachers are still teaching writing the way they were taught and that they are just de-motivating the students.

"The time given to the writing activities inside the class is not enough. Lack of vocabulary and motivation are also among the causes of weakness in writing skill." said one teacher.

"It can be said that both teachers and students are to blame. Some teachers do not adopt new techniques in teaching writing and some students never take matters seriously, as a result weakness in English in general and writing skill in particular can occur" said another teacher. "The students have not good opportunity to develop their skill of writing in classroom and out of classroom. After completing their course, they face writing problems in their academic work, they will not able to use their English writing proficiency in real life situations in fact they will go wastage" replied the other teacher.

"Teaching strategies is responsible for the drawback in students writing" one teacher said. "The way the teacher teaches writing can play a role in developing the student writing skill. Moreover, the writing activities which are given to the students are still not enough to motivate and encourage students to practice the writing skill properly".

What could be gleaned from the ideas of the teachers, as a whole, was that lack of adequate vocabulary and motivation, students' unwillingness and misinterpretations of their responsibilities as students, and the time allotted to the classroom writing activities were among the most common reasons for students' weakness in the English writing skill.

\section{Discussion}

From the above findings, the researchers deduced that there are a number of factors that take part in the weakness of the Iranian students in the English writing skills; interlingual errors standing ahead of them. Thus, we have to accept the hypothesis that "the interference of the mother tongue is a severe problem in EFL and ESL writing contexts" since, based on the findings, more than eighty percent of the total number of errors related to this category.

A look at types of errors learners made shows that most errors occurred as a result of L1 interference while some are due to incomplete instruction or imperfect mastery of L2. The strategies they used revealed some aspects of the learning process and learner language system; that is, interlanguage. This is in line with findings of other studies reviewed earlier in this study (e.g. Abbasi \& Karimian, 2011; Behjat \& Sadeghi, 2010; Sadeghi, 2009). Moreover, it was reasonable to accept the fact that "if the writers make use of L1 syntactic properties and relate them to L2 structures, they will cause errors in some contexts and lead to the gap between L1 and L2 linguistic features". The results of this study, which in many ways are similar to the findings of previous studies, also showed the Iranian foreign language learners were not aware of rules of paragraph writing of English. It was found that in general there exist systematic errors in learners' target language.

This indicates that learners need to get familiar with L2 structures through effective instruction in order to avoid errors. Therefore, EFL teachers should pay deliberate attention to the explicit teaching of such erroneous terms and provide sufficient opportunities for learners to practice correct usage of grammatical and syntactic rules both inside and outside the classroom. It is not only the teachers' responsibility to make learners familiar with accurate grammar rules. The problematic areas are required to be identified by research findings and clarified in details explicitly in addition to their appearance in natural usage by course book designers and material developers. Through the impact of L1, namely Persian, on EFL learners' writing, it was revealed that teachers should bear in mind that transfer and interference of L1 on L2 skills has to be taken care for. As Jing (2008, p. 61) 
states, "EFL learners must accumulate knowledge about L2: only in this way they can free themselves from the negative transferor influence of their mother tongue".

Another ways for language teachers to help students correct the errors is to highlight the influences of the mother tongues on the students' learning of English is to collect these errors and ask the students to analyze them and if they could try to correct them. As far as the ideas of the professors are concerned, the lack of adequate vocabulary and motivation, students' unwillingness and misinterpretations of their responsibilities as students besides the time allotted to the classroom writing activities were among the most common reasons for students' weakness in the English writing skill.

\section{Conclusions}

As for the first research question, it could be stated that both Persian and English could interfere with the writing skill of Iranian EFL students. The first conclusion of the study could be the reconfirmation of the idea that not only first language interference can result in error commitment, but also the acquisition of a new language inadequately can lead to making errors in productive skills in general and in writing in particular. Errors stemming from L1 interference are committed because EFL learners refer to the structures of their first language when writing in L2. As L1 and L2 structures are not in harmony with one another, frequent error commitment at the lexical, syntactic and discourse levels of L2 are observed. However, as stated by Erdogan (2005, p. 265) interlingual errors, as the first source of errors, are not considered as "the persistence of old habits, but rather as signs that the learner is internalizing and investigating the system of the new language".

As for the second source of errors, that is intralingual errors, it is observed that these errors are the outcome of inadequate acquisition of L2 knowledge. The confusing nature of some L2 grammatical structures and exceptions that are present in rules of grammar make the production of L2 skills suffer from errors due to the impact of target language. EFL learners require adequate instructive feedback provided by EFL instructors to understand and internalize new structures and rules of the target language, and to avoid further error commitments, specifically in writing tasks.

As for the second question of the study, It was revealed that with regard to text genre (namely comparison/contrast, narrative, and descriptive), the frequency occurrence of errors of specific type shows variation; though the data analyses identified remarkable overlap in the common errors due to the interference of first language. It is concluded that language teachers who are in charge of teaching English writing skills have to provide instructive feedback with students' writing considering the type of errors expected to be possibly made with regard to writing genre. To this end, highlighting the relevant grammatical structures of L2 which is instructive and contributive to the improvement of writing accuracy seems essential.

Iranian EFL learners are not exceptions to the trend of error commitment. Iranian EFL students can manage to get the meaning of English texts to the extent they can figure out the message behind the text. However, they cannot apply the grammatical rules and structures of target language in their writings. The available errors, however, could be of pedagogical implications for L2 teachers. The errors in EFL learners' writings can reveal the second language acquisition process. They can lead and help EFL teachers develop proper teaching methods and provide instructive feedbacks and appropriate materials for remedial purposes.

\section{References}

Abbasi, M., \& Karimnia, A. (2011). An analysis of grammatical errors among Iranian translation students: A gender-based analysis of Iranian EFL learners' types of written errors Insights from inter-language theory. European Journal of Social Sciences, 25(4), 525-536.

Bazerman, C., \& Paradis, J. (Eds.) (1991). Textual dynamics of the professions. Madison: University of Wisconsin Press.

Behjat, F., \& Sadeghi, F. (2010). Iranian English major students' L2 grammar development: Linguistic threshold hypothesis. TESL-HJ, 13(4), 1-19.

Benson, C. (2002). Transfer/Cross-linguistic influence. ELT Journal, 56(1), 68-70. http://dx.doi.org/10.1093/elt/56.1.68

Brown, H. D. (2000). Principles of language learning and teaching (4th ed.). White Plains, NY: Longman.

Connor, U. (1996). Contrastive Rhetoric: Cross-Cultural Aspects of Second Language Writing. Cambridge University Press. http://dx.doi.org/10.1017/CBO9781139524599

Corder, S. P. (1967). The Significance of Learners' Errors. IRAL, 5, 161-170. http://dx.doi.org/10.1515/iral.1967.5.1-4.161 
Corder, S. P. (1971). Idiosyncratic Dialects and Error Analysis. IRAL, 9(2), 147-160. http://dx.doi.org/10.1515/iral.1971.9.2.147

Corder, S. P. (1981). Error Analysis and Interlanguage (3rd ed.). Oxford: Oxford University press.

Cunningworth, A. (1987). Evaluation and Selecting EFL Materials. London: Heinemann Education Book.

Ellis, R. (1985). Understanding second language acquisition. Oxford: Oxford University Press.

Ellis, R. (2005). Principles of Instructed Language Learning. System, 33, 209-224. $\mathrm{http}: / / \mathrm{dx}$.doi.org/10.1016/j.system.2004.12.006

Ellis, R. (2008). The Study of Second Language Acquisition (2nd ed.). Oxford: Oxford UniversityPress.

Erdogan, V. (2005). Contribution of Error Analysis to Foreign Language Teaching. Mersin University Journal of the Faculty of Education, 1(2), 261-270.

Fang, X., \& Xue-Mei, J. (2007). Error Analysis and the EFL Classroom Teaching. US-China Education Review, $4(9), 10-14$.

Ferris, D. (2002). Treatment of error in second language writing. Michigan: The University of Michigan Press.

Hyland, K. (2003). Second language writing. Cambridge: Cambridge University Press. http://dx.doi.org/10.1017/CBO9780511667251

Izadi-Agha, M. (2007). Analysis of written interlanguage of ESL students with Persian backgrounds (Ed.D. dissertation, Alliant International University, San Diego-California, United States). Retrieved January 29, 2009, from Dissertations \& Theses: Full Text database (UMI No. 3273296).

Jalali, S. (2012). The effects of the types of TOEFL (P\&P vs. CBT) and computer anxiety level on Iranian EFL learners' performance on TOEFL. Sheikhbahaee EFL Journal, 1(2), 35-58.

James, C. (1998). Error in language learning and use. NY: Addison Wesley Longman.

James, C. (2001). Errors in language learning and use: Exploring error analysis. Beijing: Foreign Language Teaching and Research Press.

Jing, M. (2008). Erroneous Collocations Caused by Language Transfer in Chinese EFL Writing. US-China Foreign Language, 6(9), 57-61.

Keshavarz, M. H. (2005). Contrastive analysis and error analysis. Tehran: Rahnama Publication.

Khuwaileh, A., \& Al-Shoumali, A. (2000). Writing Errors: A Study of the Writing Ability of Arab Learners of Academic English and Arabic at University. Language Culture and Curriculum, 13(2), 174-183. http://dx.doi.org/10.1080/07908310008666597

Lakkis, K., \& Abdel-Malak, M. (2000). Understanding the transfer of prepositions. English Teaching Forum, 38(3), 26-33.

Lalande, J. (1982). Reducing Composition errors: An experiment. Modern language Journal, 66, 140-149. http://dx.doi.org/10.1111/j.1540-4781.1982.tb06973.x

Latif, M. M. A. (2009). Toward a new process-based indicator for measuring writing fluency: evidence from L2 writers' think-aloud protocols. The Canadian Modern Language Review/La Revue canadienne des langues vivantes, 65(4), 531-558. http://dx.doi.org/10.3138/cmlr.65.4.531

Nayernia, M. (2011). Writing errors, what they can tell a teacher? MJAL, 3(2), 200-218.

Norrish, J. (1987). Language Learning and their Errors. London: Macmillan Publisher Ltd.

Reid, J. M. (1993). Teaching ESL writing. NJ: Prentice Hall Regents.

Richards, J. C., \& Renandya, W. A. (Eds.) (2002). Methodology in Language Teaching: An Anthology of Current Practice. Cambridge: Cambridge University Press. http://dx.doi.org/10.1017/CBO9780511667190

Richards, J. C., \& Schmidt, R. (Eds.). (2002). Longman dictionary of language teaching and applied linguistics (3rd ed.). London: Longman.

Sadeghi, K. (2009). Collocational Differences between L1 and L2: Implications for EFL Learners and Teachers. Tesl Canada Journal, 26(2), 100-124.

Sattari, A. (2012). An analysis of grammatical errors in Iranian students' English writings. Iranian EFL Journal, $8(2), 143-157$. 
Scovel, T. (2001). Learning new languages: a guide to second language acquisition. London: Heinle \& Heinle.

Selinker, L. (1972). Interlanguage. International Review of Applied Linguistics, 10, 209-230. http://dx.doi.org/10.1515/iral.1972.10.1-4.209

Selinker, L., \& Lakshmanan, U. (1992). Language transfer and fossilization: The multiple effects principle. In S. Gass, \& L. Selinker (Eds.), Language transfer in language learning (pp. 197-216). Amsterdam: John Benjamins. http://dx.doi.org/10.1075/lald.5.13sel

Shahrokhi, M., \& Lotfi, A. R. (2012). Manifestation of Transitivity Parameters in Persian Conversations: A Comparative Study. Procedia-Social and Behavioral Sciences, 46, 635-642. http://dx.doi.org/10.1016/j.sbspro.2012.05.176

Shahrokhi, M., \& Moradmand, S. (2014). A Comparative Study of the Use of Collocation in Iranian High School Textbooks and American English File Books. International Journal of Applied Linguistics \& English Literature, 3(3), 58-64. http://dx.doi.org/10.7575/aiac.ijalel.v.3n.3p.58

Sridhar S. N. (1985). Contrastive Analysis, Error Analysis and Interlanguage: Three Phases of One Goal. In J. Fisiak (Ed.), Contrastive Linguistics and Language Teacher (pp. 207-241). Oxford: Pergamon

\section{Copyrights}

Copyright for this article is retained by the author(s), with first publication rights granted to the journal.

This is an open-access article distributed under the terms and conditions of the Creative Commons Attribution license (http://creativecommons.org/licenses/by/3.0/). 